\title{
Perancangan SCADA Software dengan Wonderware InTouch Recipe Manager dan SQL Access Manager pada Simulator Proses Pencampuran Bahan
}

\author{
Handy Wicaksono, Resmana Lim, William Sutanto \\ Jurusan Teknik Elektro UK Petra, Surabaya 60236 \\ email : handy@peter.petra.ac.id
}

\begin{abstract}
ABSTRAK
Banyak industri yang sudah menggunakan sistem automasi dengan menggunakan PLC (Programmable Logic Controller) dan SCADA (Supervisory Control And Data Acquisition). Salah satu software untuk membuat program SCADA adalah Wonderware InTouch. Untuk mengelola data dalam bentuk recipe dan database, Wonderware InTouch mempunyai program-program tambahan yaitu Recipe Manager dan SQL Access Manager. Pada penelitian ini, akan digunakan proses pembuatan kertas sebagai contoh kasus yang terjadi di industri. Untuk itu akan dibuat simulator plant yang dihubungkan ke PLC Omron C200HG dan dari PLC dihubungkan ke komputer dengan software Wonderware InTouch. Pada program SCADA yang dibuat, pengguna dapat memilih, menghapus dan membuat resep baru yang berisi komposisi campuran bahan. Setelah sistem dijalankan, data - data sensor akan disimpan ke dalam database dan dapat dilihat oleh pengguna. Fitur keamanan, penggambaran data dalam bentuk grafik (trend), dan alarm juga ditambahkan pada program ini. Berdasarkan hasil pengujian secara keseluruhan terhadap program SCADA yang dihubungkan dengan PLC dan simulator mixing plant pada proses pembuatan kertas, maka dapat disimpulkan bahwa semua fitur berjalan dengan baik.
\end{abstract}

Kata kunci : SCADA, wonderware inTouch, recipe manager, SQL access manager

\begin{abstract}
Nowadays, many industries has applied automation system by using PLC (Programmable Logic Controller) and SCADA (Supervisory Control And Data Acquisition). Wonderware InTouch is a kind of SCADA software available. In order to organize data in recipe and database, Wonderware provides Recipe Manager and SQL Access Manager. In this research, the process of paper making will be used as an industrial case study. In order to describe the process, a simulator plant will be made. It connects to PLC Omron C200HG and a computer which installed with Wonderware InTouch. In SCADA software that has been made, user can choose, delete, and create new recipe which is contained material mixture composition. When the system is running, sensor datas will be stored in a database and it can be seen by user. Security, trend, and alarm features are available too in this program. Based on overall experiment results through SCADA program that connected to PLC and simulator mixing plant, it can be concluded that all features in the program can run well.
\end{abstract}

Keywords: SCADA, wonderware inTouch, recipe manager, SQL access manager

\section{PENDAHULUAN}

Saat ini teknologi automasi berbasis PLC (Programmable Logic Controller) banyak dipakai di dunia industri. PLC yang menggunakan ladder diagram untuk pemrogramannya merupakan pengendali yang handal khususnya untuk sistem-sistem yang bersifat sekuensial, misal: manufaktur.

Salah satu kekurangan PLC ialah pada bagian interface yang tidak user friendly, sehingga operator sulit untuk mengamati plant yang dikendalikan PLC. Selain itu juga muncul kebutuhan untuk menyimpan data ke dalam database. Karena itu muncullah

Catatan: Diskusi untuk makalah ini diterima sebelum tanggal 1 Juni 2008. Diskusi yang layak muat akan diterbitkan pada Jurnal Teknik Elektro volume 8, nomor 2, September 2008. berbagai macam software SCADA dari bermacammacam vendor, misalnya: Wonderware, Intellution WinCC, SciTech, dan lain-lain. Software tersebut biasanya memiliki fitur-fitur lengkap, kompleks dan tentu saja memiliki harga yang tidak murah.

Seiring dengan perkembangan internet, kebutuhan untuk dapat mengakses sisem SCADA dari jarak jauh melalui internet. Hal ini memudahkan pemilik perusahaan yang berada jauh dari plant yang dimilikinya, namun masih ingin mengamati dan mengendalikan plant tersebut. Kebutuhan tersebut dipenuhi oleh vendor SCADA software, misalnya Wonderware yang mengeluarkan produk SuiteVoyager.

Masalah yang akan dijelaskan dalam penelitian ini adalah bagaimana membuat SCADA software yang 
sederhana dan murah untuk suatu plant yang dikontrol oleh PLC OMRON. SCADA software ini juga dapat diakses dari jarak jauh melalui internet. Plant yang akan dikendalikan ialah miniatur rumah cerdas, dimana alat yang akan dikontrol adalah lampu, fan dan lampu dimmer dari miniatur tersebut.

\section{PERANCANGAN SISTEM}

Dari hasil studi terhadap proses pembuatan kertas pada tahap Stock preparation, maka dilakukan penyederhanaan dari keseluruhan plant pembuatan kertas tahap persiapan tersebut (lihat Gambar 1). Gambar dari penyederhanaan plant tersebut adalah sebagai berikut:

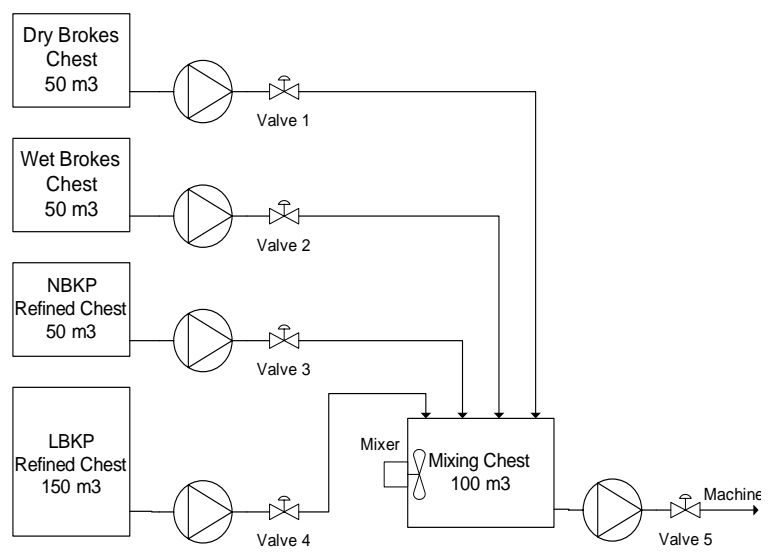

Gambar 1. Mixing plant pada proses pembuatan kertas[1]

Secara umum perencanaan dan pembuatan alat berdasarkan dari blok diagram sistem yang diinginkan. Berikut adalah gambar dari blok diagram sistem:

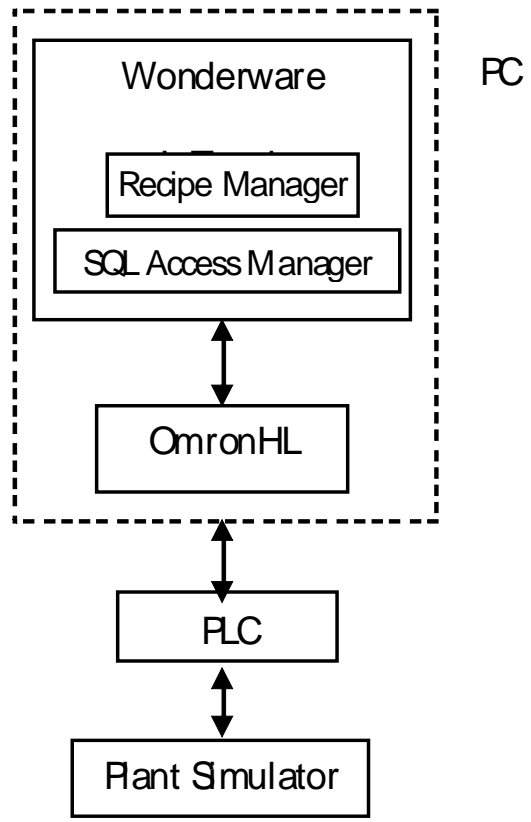

Gambar 2. Blok diagram sistem

\section{Hardware}

Perencanaan dan pembuatan hardware (perangkat keras) meliputi pembuatan simulator plant, PLC, dan wiring (pengkabelan) antara simulator plant dengan PLC.

\section{Simulator Plant}

Simulator Plant terdiri dari rangkaian input dan rangkaian output, yang nantinya rangkaian-rangkaian ini akan dihubungkan dengan $P L C$.

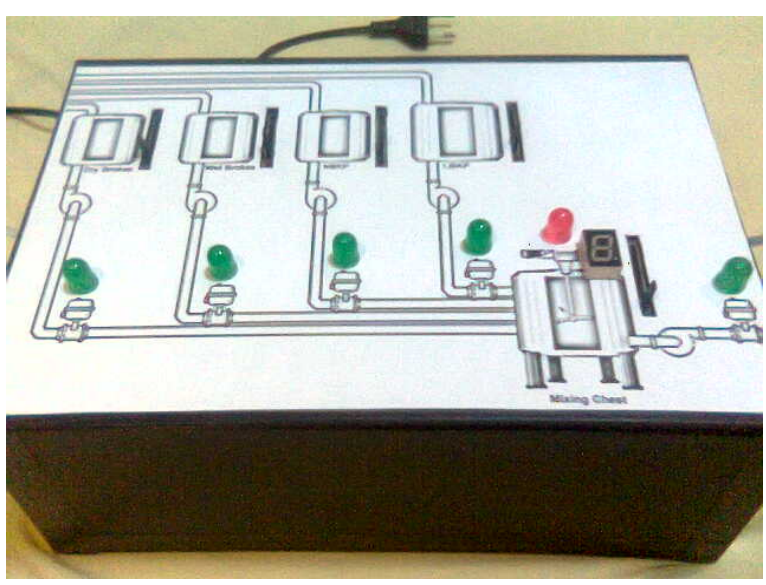

Gambar 3. Simulator plant

PLC

PLC yang digunakan adalah PLC Omron C200HG yang terdiri dari $\mathrm{CPU}$ tipe $\mathrm{C} 200 \mathrm{HG}-\mathrm{CPU} 43, \mathrm{C} 200 \mathrm{H}-$ AD002 Analog Input Unit, C200H-OC222 Relay Output Unit.

\section{Wiring Input Analog}

Pada simulator plant terdapat 5 buah potensiometer sebagai pengganti 5 buah sensor level analog (water level) pada 5 buah tangki. Output (0-10 Volt) dari kelima buah sensor analog ini masuk ke pin-pin input dari $\mathrm{C} 200 \mathrm{H}-\mathrm{AD} 002$ Analog Input Unit. Wiring-nya sebagai berikut:

Tabel 1. Wiring input analog PLC

\begin{tabular}{lcll}
\hline \multirow{2}{*}{ Input } & \multicolumn{3}{c}{ C200H-AD002 } \\
\cline { 2 - 4 } & Pin no. & \multicolumn{2}{c}{ Keterangan } \\
\hline Sensor 1 & 1 & Voltage input (+) & Input 1 \\
GND & 3 & Common (-) & \\
Sensor 2 & 23 & Voltage input (+) & Input 2 \\
GND & 25 & Common (-) & \\
Sensor 3 & 26 & Voltage input (+) & Input 4 \\
GND & 28 & Common (-) & \\
Sensor 4 & 29 & Voltage input (+) & Input 6 \\
GND & 31 & Common (-) & \\
Sensor 5 & 32 & Voltage input (+) & Input 8 \\
GND & 34 & Common (-) & \\
\hline
\end{tabular}




\section{Wiring Output Diskrit}

Pada simulator plant terdapat 6 buah rangkaian output LED dan sebuah decoded seven segment display. Pin-pin output PLC dihubungkan ke rangkaian output LED dan seven segment. Wiring-nya sebagai berikut:

Tabel 2. Wiring output diskrit PLC

\begin{tabular}{cl}
\cline { 1 - 2 } C200H-OC222 & \multicolumn{1}{c}{ Output } \\
\cline { 1 - 2 } Pin no. & \\
\cline { 1 - 2 } 0 & Valve 1 \\
1 & Valve 2 \\
2 & Valve 3 \\
3 & Valve 4 \\
4 & Mixer \\
5 & Valve5 \\
6 & input A 7-seg \\
7 & input B 7-seg \\
8 & input C 7-seg \\
9 & input D 7-seg \\
COM & 12 VDC \\
\hline
\end{tabular}

\section{Software}

Program untuk menjalankan sistem ini dibuat pada Wonderware, jadi Wonderware berfungsi untuk mengontrol sekaligus memonitor. Pada PLC tetap diprogram menggunakan ladder logic beserta parameter-parameternya untuk menerima input, dan mengeluarkan output. Untuk pemrograman PLC menggunakan software SYSMAC-CPT. Dan untuk menghubungkan Wonderware InTouch dengan PLC dibutuhkan software I/O driver OmronHL.

\section{SYSMAC-CPT}

Berikut ini adalah tabel address I/O PLC:

Tabel 3. Address input PLC

\begin{tabular}{cc}
\hline Address & Device \\
\hline IR 00101 & Sensor 1 \\
IR 00102 & Sensor 2 \\
IR 00104 & Sensor 3 \\
IR 00106 & Sensor 4 \\
IR 00108 & Sensor 5 \\
\hline
\end{tabular}

Tabel 4. Address output PLC

\begin{tabular}{cc}
\hline Address & Device \\
\hline IR 00500 & Valve 1 \\
IR 00501 & Valve 2 \\
IR 00502 & Valve 3 \\
IR 00503 & Valve 4 \\
IR 00504 & Mixer \\
\hline
\end{tabular}

\begin{tabular}{cc}
\hline Address & Device \\
\hline IR 00505 & Valve5 \\
IR 00506 & input A 7-seg \\
IR 00507 & input B 7-seg \\
IR 00508 & input C 7-seg \\
IR 00509 & input D 7-seg \\
\hline
\end{tabular}

\section{Wonderware InTouch}

Wonderware InTouch berfungsi sebagai SCADA, yang berarti mengontrol, memonitor, serta menyimpan dan mengakses data.

\section{Flowchart Sistem}

Sebelum membuat program SCADA, perlu diketehui terlebih dahulu proses kerja dari sistem yang akan dibuat. Sistem tersebut memiliki fasilitas pengaturan resep bahan-bahan yang ada, untuk itu digunakan program Recipe Manager. Dan juga memiliki fasilitas pencatatan data ke dalam database Microsoft Access, untuk itu digunakan SQL Access Manager. Selain itu, sistem tersebut juga memiliki fitur-fitur lain yaitu security, alarm, dan real time trend. Setelah mengetahui proses kerja, tahap berikutnya adalah membuat flowchart dari sistem tersebut. Perhatikan Gambar 4 yang merupakan flowchart dari sistem yang akan mendasari pembuatan program Wonderware InTouch.

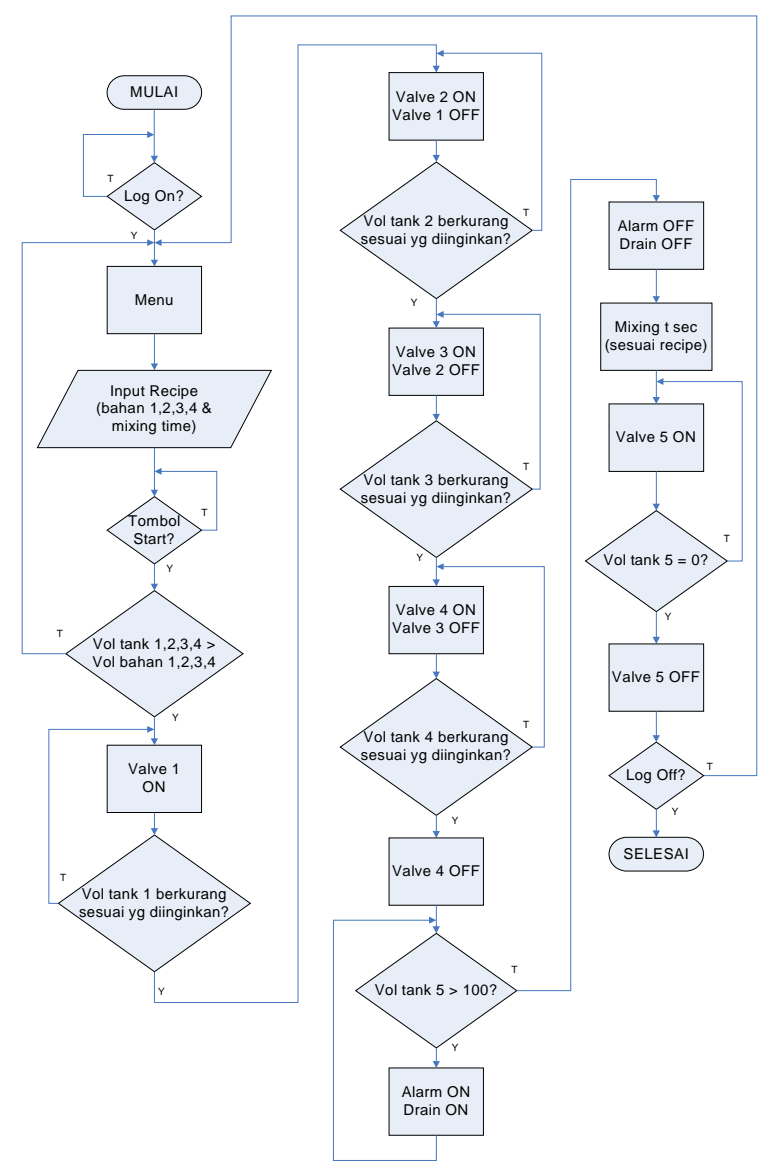

Gambar 4. Flowchart sistem 


\section{InTouch Tagnames}

Untuk mengakses/mongontrol input dan output dari PLC, membuat animasi, melakukan konversi/perhitungan, maupun penanganan data atau mengakses database perlu mendefinisikan InTouch tagnames terlebih dahulu. Pada Tabel 5 akan dijabarkan namanama dari tagname yang dibuat pada InTouch.

Tabel 5. InTouch tagnames

\begin{tabular}{|c|c|c|}
\hline Tagname & Tag Type & Fungsi \\
\hline A & I/O Discrete & $\begin{array}{l}\text { ON/OFF input A 7- } \\
\text { seg }\end{array}$ \\
\hline B & I/O Discrete & $\begin{array}{l}\text { ON/OFF input B 7- } \\
\text { seg }\end{array}$ \\
\hline BindList & $\begin{array}{l}\text { Memory } \\
\text { Message }\end{array}$ & Nama Bind List \\
\hline blade & $\begin{array}{l}\text { Memory } \\
\text { Discrete }\end{array}$ & Animasi mixer \\
\hline $\mathrm{C}$ & I/O Discrete & $\begin{array}{l}\text { ON/OFF input C 7- } \\
\text { seg }\end{array}$ \\
\hline ConnectionID & $\begin{array}{l}\text { Memory } \\
\text { Integer }\end{array}$ & $\begin{array}{l}\text { Nomor } \\
\text { ConnectionId }\end{array}$ \\
\hline D & I/O Discrete & $\begin{array}{l}\text { ON/OFF input D 7- } \\
\text { seg }\end{array}$ \\
\hline Directory & $\begin{array}{l}\text { Memory } \\
\text { Message }\end{array}$ & $\begin{array}{l}\text { Alamat folder } \\
\text { program }\end{array}$ \\
\hline ErrorMsg & $\begin{array}{l}\text { Memory } \\
\text { Message }\end{array}$ & $\begin{array}{l}\text { Pesan error SQL } \\
\text { AM }\end{array}$ \\
\hline higher & $\begin{array}{l}\text { Memory } \\
\text { Discrete }\end{array}$ & $\begin{array}{l}\text { Animasi pesan } \\
\text { higher }\end{array}$ \\
\hline ing1 & Memory Real & $\begin{array}{l}\text { Prosentase Dry } \\
\text { Brokes }\end{array}$ \\
\hline ing1a & Memory Real & Perhitungan \\
\hline ing2 & Memory Real & $\begin{array}{l}\text { Prosentase Wet } \\
\text { Brokes }\end{array}$ \\
\hline ing2a & Memory Real & Perhitungan \\
\hline ing3 & Memory Real & Prosentase NBKP \\
\hline ing3a & Memory Real & Perhitungan \\
\hline ing4 & Memory Real & Prosentase LBKP \\
\hline ing $4 a$ & Memory Real & Perhitungan \\
\hline ket & Memory Real & Database \\
\hline LogOn & $\begin{array}{l}\text { Memory } \\
\text { Discrete }\end{array}$ & Security \\
\hline lower & $\begin{array}{l}\text { Memory } \\
\text { Discrete }\end{array}$ & $\begin{array}{l}\text { Animasi pesan } \\
\text { lower }\end{array}$ \\
\hline mixer & I/O Discrete & ON/OFF mixer \\
\hline mixing & $\begin{array}{l}\text { Memory } \\
\text { Integer }\end{array}$ & Lama mixing (detik) \\
\hline mixinga & $\begin{array}{l}\text { Memory } \\
\text { Integer }\end{array}$ & Perhitungan \\
\hline mixingb & $\begin{array}{l}\text { Memory } \\
\text { Integer }\end{array}$ & Perhitungan \\
\hline OperatorName & $\begin{array}{l}\text { Memory } \\
\text { Message }\end{array}$ & Nama Operator \\
\hline OrderByExpr & $\begin{array}{l}\text { Memory } \\
\text { Message }\end{array}$ & Database \\
\hline
\end{tabular}

\begin{tabular}{|c|c|c|}
\hline Tagname & Tag Type & Fungsi \\
\hline pesanmixing & $\begin{array}{l}\text { Memory } \\
\text { Discrete }\end{array}$ & $\begin{array}{l}\text { Animasi pesan } \\
\text { mixing }\end{array}$ \\
\hline recipename & $\begin{array}{l}\text { Memory } \\
\text { Message }\end{array}$ & Nama Recipe \\
\hline recipetemplate & $\begin{array}{l}\text { Memory } \\
\text { Message }\end{array}$ & Alamat Recipe \\
\hline RecordNumber & $\begin{array}{l}\text { Memory } \\
\text { Integer }\end{array}$ & $\begin{array}{l}\text { Nomor record } \\
\text { Database }\end{array}$ \\
\hline ResultCode & $\begin{array}{l}\text { Memory } \\
\text { Integer }\end{array}$ & Database \\
\hline SQLNumRows & $\begin{array}{l}\text { Memory } \\
\text { Integer }\end{array}$ & $\begin{array}{l}\text { Jumlah record } \\
\text { Database }\end{array}$ \\
\hline Start & $\begin{array}{l}\text { Memory } \\
\text { Discrete }\end{array}$ & Tombol Start \\
\hline TableName & $\begin{array}{l}\text { Memory } \\
\text { Message }\end{array}$ & $\begin{array}{l}\text { Nama Tabel } \\
\text { Database }\end{array}$ \\
\hline tanggal & $\begin{array}{l}\text { Memory } \\
\text { Message }\end{array}$ & Database \\
\hline $\operatorname{tank1}$ & I/O Real & Water level Tank 1 \\
\hline tankla & Memory Real & Perhitungan \\
\hline $\operatorname{tank} 1 \mathrm{~b}$ & Memory Real & Perhitungan \\
\hline tankld & Memory Real & Database \\
\hline $\operatorname{tank2}$ & I/O Real & Water level Tank 2 \\
\hline $\operatorname{tank} 2 \mathrm{a}$ & Memory Real & Perhitungan \\
\hline $\operatorname{tank} 2 \mathrm{~b}$ & Memory Real & Perhitungan \\
\hline $\operatorname{tank} 2 d$ & Memory Real & Database \\
\hline $\operatorname{tank3}$ & I/O Real & Water level Tank 3 \\
\hline $\operatorname{tank3a}$ & Memory Real & Perhitungan \\
\hline $\operatorname{tank} 3 b$ & Memory Real & Perhitungan \\
\hline $\operatorname{tank3d}$ & Memory Real & Database \\
\hline $\operatorname{tank} 4$ & I/O Real & Water level Tank 4 \\
\hline $\operatorname{tank} 4 \mathrm{a}$ & Memory Real & Perhitungan \\
\hline $\operatorname{tank} 4 \mathrm{~b}$ & Memory Real & Perhitungan \\
\hline $\operatorname{tank} 4 d$ & Memory Real & Database \\
\hline $\operatorname{tank5}$ & I/O Real & Water level Tank 5 \\
\hline $\operatorname{tank} 5 \mathrm{a}$ & Memory Real & Perhitungan \\
\hline $\operatorname{tank5d}$ & Memory Real & Database \\
\hline Template & $\begin{array}{l}\text { Memory } \\
\text { Message }\end{array}$ & $\begin{array}{l}\text { Nama Table } \\
\text { Template }\end{array}$ \\
\hline total & Memory Real & $\begin{array}{l}\text { Jumlah prosentase } \\
\text { Recipe }\end{array}$ \\
\hline Valve1 & I/O Discrete & ON/OFF Valve 1 \\
\hline Valve2 & I/O Discrete & ON/OFF Valve 2 \\
\hline Valve3 & I/O Discrete & ON/OFF Valve 3 \\
\hline Valve4 & I/O Discrete & ON/OFF Valve 4 \\
\hline Valve5 & I/O Discrete & ON/OFF Valve 5 \\
\hline waktu & $\begin{array}{l}\text { Memory } \\
\text { Message }\end{array}$ & Database \\
\hline WhereExpr & $\begin{array}{l}\text { Memory } \\
\text { Message }\end{array}$ & Database \\
\hline
\end{tabular}

\section{Recipe Manager}

Pada aplikasi Recipe Manager dibuat sebuah recipe template file bernama "recipe.csv". Ada 3 buah template yang perlu didefinisikan, pertama mendefinisikan Template Definition, sebagai berikut: 
Tabel 6. Template definition

\begin{tabular}{lll}
\hline & \multicolumn{1}{c}{ Item Name } & Item Type \\
\hline Item 1 & Dry Brokes & Analog \\
Item 2 & Wet Brokes & Analog \\
Item 3 & NBKP & Analog \\
Item 4 & LBKP & Analog \\
Item 5 & Mixing Time & Analog \\
\hline
\end{tabular}

Setelah itu mendefinisikan Unit Definition, untuk menghubungkan tagname InTouch dengan item pada recipe template file.

Tabel 7. Unit definition

\begin{tabular}{clll}
\hline \multirow{2}{*}{$\begin{array}{c}\text { Unit } \\
\text { Name }\end{array}$} & \multicolumn{1}{c}{$\begin{array}{c}\text { Item } \\
\text { Name }\end{array}$} & Item Type & Unit 1 \\
\cline { 2 - 4 } & & & $\mathrm{a}$ \\
\hline Item 1 & $\begin{array}{l}\text { Dry } \\
\text { Brokes }\end{array}$ & Analog & ing1 \\
Item 2 & Wet & Analog & ing2 \\
& Brokes & & \\
Item 3 & NBKP & Analog & ing3 \\
Item 4 & LBKP & Analog & ing4 \\
Item 5 & Mixing & Analog & mixing \\
& Time & & \\
\hline
\end{tabular}

Terakhir mendefinisikan Recipe Definition untuk membuat recipe. Selain melalui Recipe Definition dapat dibuat recipe melalui program SCADA yang telah dibuat.

Tabel 8. Recipe definition

\begin{tabular}{|c|c|c|c|c|}
\hline \multirow{2}{*}{$\begin{array}{c}\text { Recipe } \\
\text { Names }>>>\end{array}$} & $\begin{array}{c}\text { Item } \\
\text { Name }\end{array}$ & $\begin{array}{l}\text { Item } \\
\text { Type }\end{array}$ & $\begin{array}{c}\text { Recipe } \\
1 \\
\end{array}$ & $\begin{array}{c}\text { Recipe } \\
2 \\
\end{array}$ \\
\hline & & & r1 & $\mathrm{r} 2$ \\
\hline Item 1 & \multicolumn{2}{|c|}{ Dry Brokes Analog } & 10 & 15 \\
\hline Item 2 & $\begin{array}{l}\text { Wet } \\
\text { Brokes }\end{array}$ & Analog & 5 & 5 \\
\hline Item 3 & NBKP & Analog & 15 & 20 \\
\hline Item 4 & LBKP & Analog & 70 & 60 \\
\hline Item 5 & $\begin{array}{l}\text { Mixing } \\
\text { Time }\end{array}$ & Analog & 10 & 20 \\
\hline
\end{tabular}

\section{SQL Access Manager}

Pada aplikasi SQL Access Manager dibuat Bind List untuk menghubungkan antara tagname InTouch dengan nama kolom pada database Ms Access. Bind List perlu untuk didefinisikan terlebih dahulu sebelum menggunakan SQL Functions khususnya yang memakai parameter Bind List. Konfigurasinya dapat dilihat pada Tabel 9.

Setelah itu membuat Table Template. Pada Table Template didefinisikan parameter-parameter untuk membuat tabel yang baru. Konfigurasinya dapat dilihat pada Tabel 10 .
Tabel 9. Bind list configuration

\begin{tabular}{ll}
\hline Tagname.FieldName & \multicolumn{1}{c}{ Column Name } \\
\hline Tanggal & Tanggal \\
Waktu & Waktu \\
recipename & Recipe \\
tank1d & Tank_1 \\
tank2d & Tank_2 \\
tank3d & Tank_3 \\
tank4d & Tank_4 \\
tank5d & Tank_5 \\
Ket & Keterangan \\
OperatorName & Nama_Operator \\
\hline
\end{tabular}

Tabel 10. Table template configuration

\begin{tabular}{|c|c|c|c|}
\hline Column Name & $\begin{array}{c}\text { Column } \\
\text { Type }\end{array}$ & $\begin{array}{c}\text { Allow } \\
\text { Null }\end{array}$ & $\begin{array}{l}\text { Index } \\
\text { Type }\end{array}$ \\
\hline Tanggal & text & Null & $\begin{array}{l}\text { Non- } \\
\text { Unique }\end{array}$ \\
\hline Waktu & text & Null & $\begin{array}{l}\text { Non- } \\
\text { Unique }\end{array}$ \\
\hline Recipe & text & Null & $\begin{array}{l}\text { Non- } \\
\text { Unique }\end{array}$ \\
\hline Tank_1 & number & Null & $\begin{array}{l}\text { Non- } \\
\text { Unique }\end{array}$ \\
\hline Tank_2 & number & Null & $\begin{array}{l}\text { Non- } \\
\text { Unique }\end{array}$ \\
\hline Tank_3 & number & Null & $\begin{array}{l}\text { Non- } \\
\text { Unique }\end{array}$ \\
\hline Tank_4 & number & Null & $\begin{array}{l}\text { Non- } \\
\text { Unique }\end{array}$ \\
\hline Tank_5 & number & Null & $\begin{array}{l}\text { Non- } \\
\text { Unique }\end{array}$ \\
\hline Keterangan & text & Null & $\begin{array}{l}\text { Non- } \\
\text { Unique }\end{array}$ \\
\hline Nama_Operator & text & Null & $\begin{array}{l}\text { Non- } \\
\text { Unique }\end{array}$ \\
\hline
\end{tabular}

Tampilan Program Keseluruhan

Halaman-halaman terbagi menjadi: halaman keamanan, halaman utama, halaman resep, dan halaman SQL. Tampilan dapat dilihat pada Gambar 5 sampai Gambar 8.

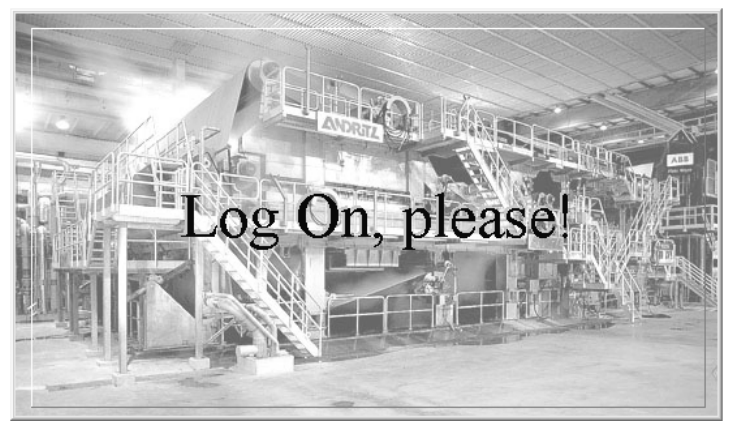

Gambar 5. Halaman keamanan 
Halaman kemanan berfungsi supaya tidak sembarang orang tidak dapat masuk dalam program ini. Sedang halaman utama berguna untuk menampilkan proses pencampuran yang terjadi. Halaman resep digunakan untuk untuk mengatur prosentase masing - masing bahan campuran. Halaman SQL sebagai halaman terakhir berfungsi menampilkan ataupun mengupdate isi database dari resep - resep yang ada.

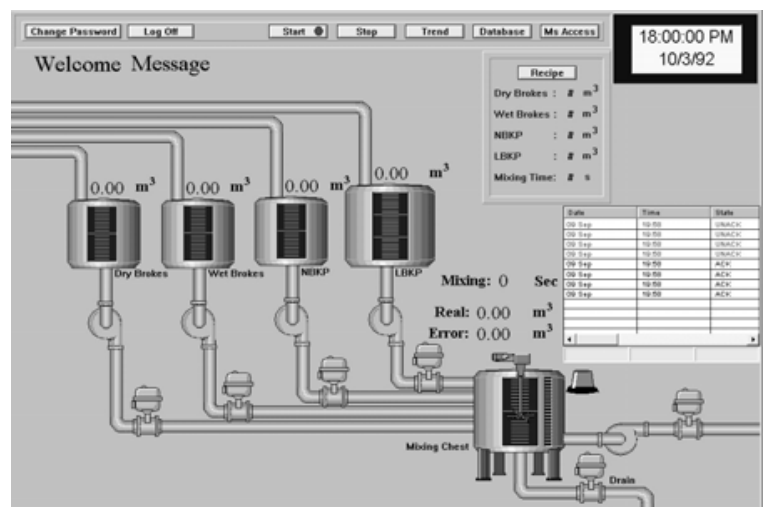

Gambar 6. Halaman utama

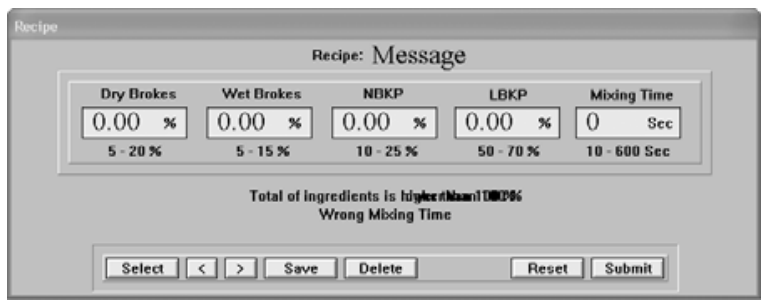

Gambar 7. Halaman resep

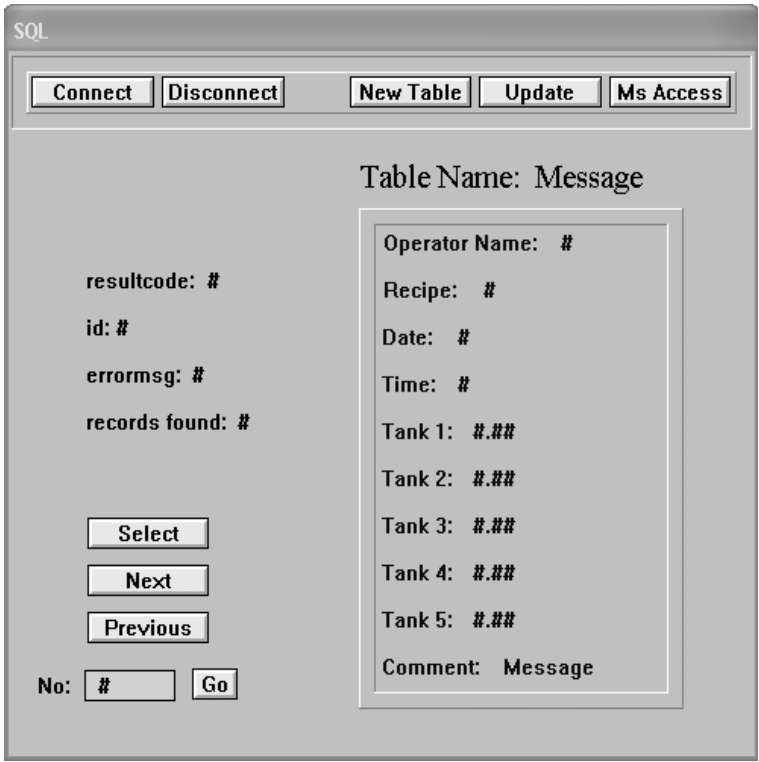

Gambar 8. Halaman SQL

\section{PENGUJIAN SISTEM}

Pengujian dilakukan dengan meng-hubungkan Simulator Plant dengan PLC dan dengan Wonderware InTouch.
Ketika program SCADA Wonderware InTouch dijalankan (runtime), maka proses kontrol pada plant mulai aktif. Berikut adalah urutan proses yang terjadi:

a. User harus log on terlebih dahulu. Bisa log on dengan user name "administrator" dan dengan password "wonderware"; dengan user name "william" dan dengan password "23402054"; atau dengan user name "operator" dan dengan password " 123 ".

Catatan: user "operator" tidak dapat mengakses recipe dan database; tombol Recipe, Database, dan Ms Access tidak dapat ditekan (disable).

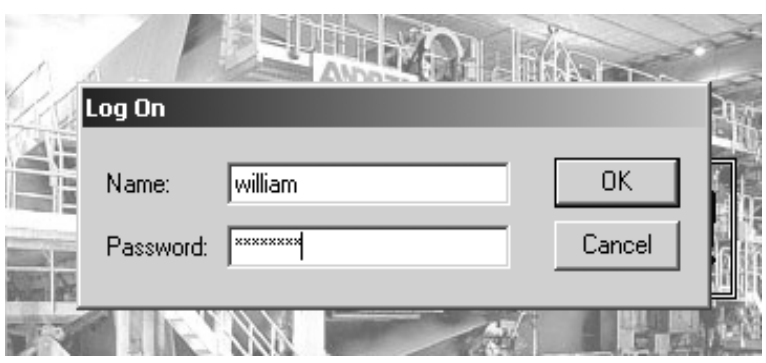

Gambar 9. Log on

b. Mengkoneksikan InTouch dengan database, dengan menekan tombol Database pada main window, lalu menekan tombol Connect pada window $S Q L$ yang muncul.

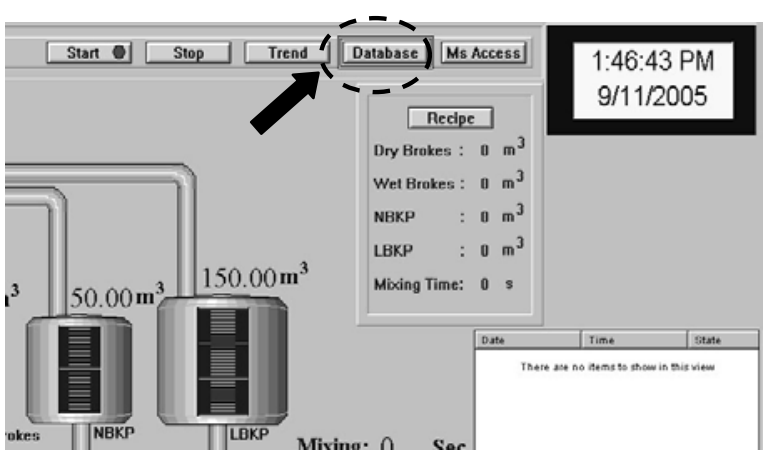

Gambar 10. Mengkoneksikan database Bagian 1

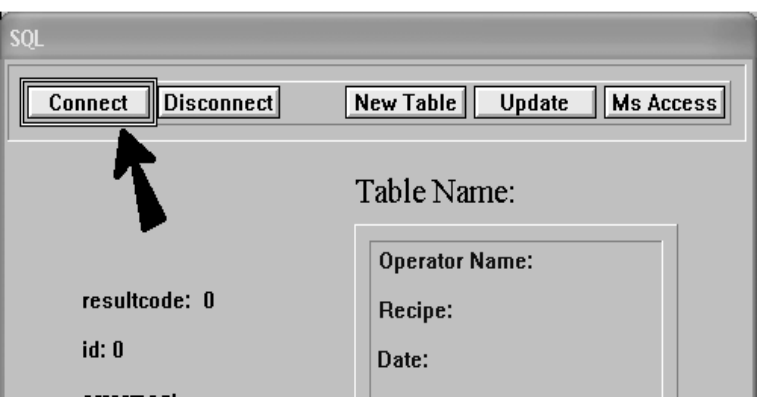

Gambar 11. Mengkoneksikan Database Bagian 2

c. Pada halaman resep diisikan resep yang diinginkan untuk proses mixing. Kemudian tekan tombol Submit. 


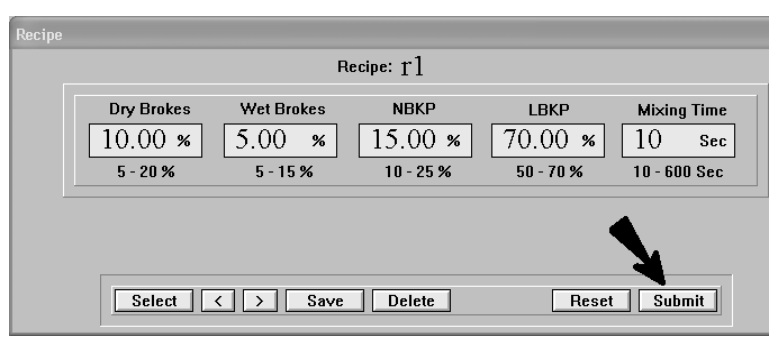

Gambar 12. Mengatur recipe

d. Menekan tombol Start, dan proses mixing akan mulai berjalan. Pada saat tombol Start ditekan, maka valve 1 akan ON. Database akan mencatat data pada awal proses, selama proses tiap 5 detik, dan pada akhir proses. Apabila pada saat proses sedang berlangsung dan ditekan tombol Stop, maka proses akan berhenti.

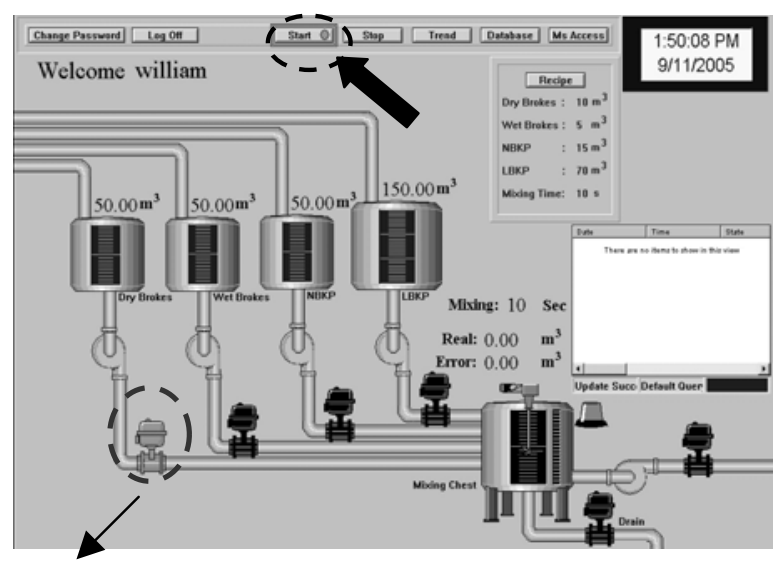

Valve 1

Gambar 13. Start

Isi tank 1 berkurang sesuai yang diinginkan $\rightarrow$ valve $1 \mathrm{OFF}$ dan valve $2 \mathrm{ON}$.

Jika volume tank 5 lebi besar dari $100 \mathrm{~m}^{3}$ maka alarm akan ON.

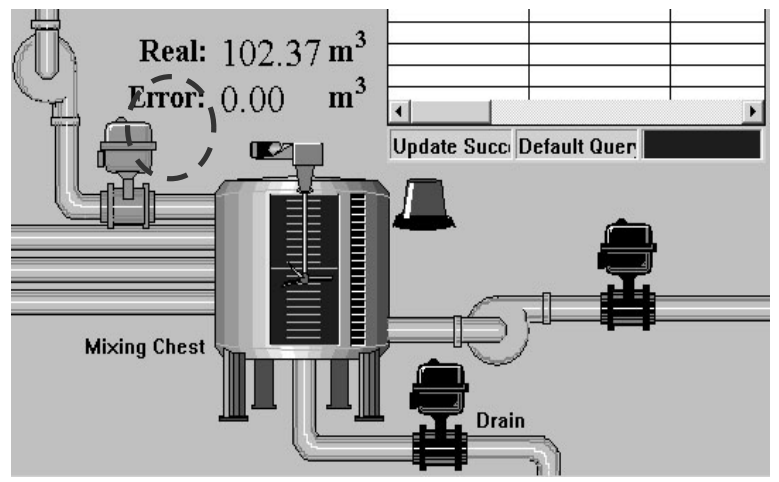

Gambar 14. In process bagian 4

Setelah isi tank 4 berkurang sesuai yang diinginkan $\rightarrow$ Drain ON sampai volume tank $5 \leq 100 \mathrm{~m}^{3}$ kemudian di-mixing selama $\mathrm{t}$ detik (sesuai recipe).

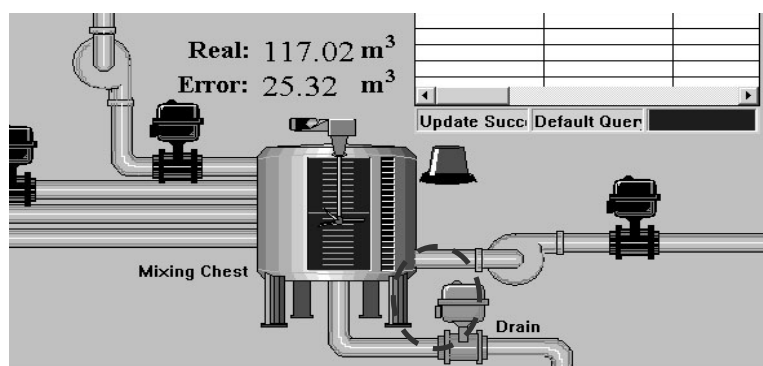

Gambar 15. In process bagian 5

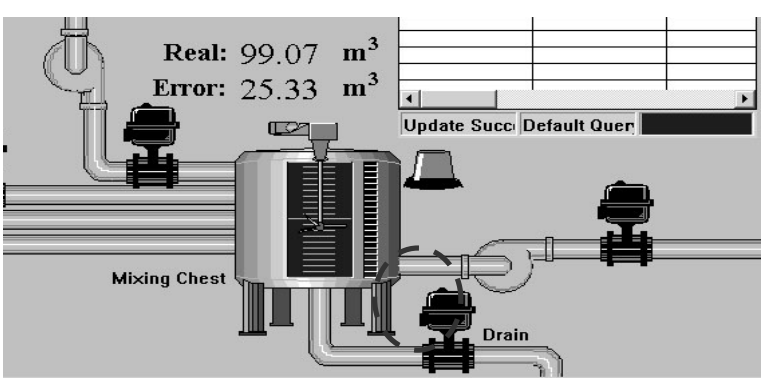

Gambar 16. In process bagian 6

Setelah proses mixing selesai, isi tank 5 ditransfer ke proses selanjutnya.

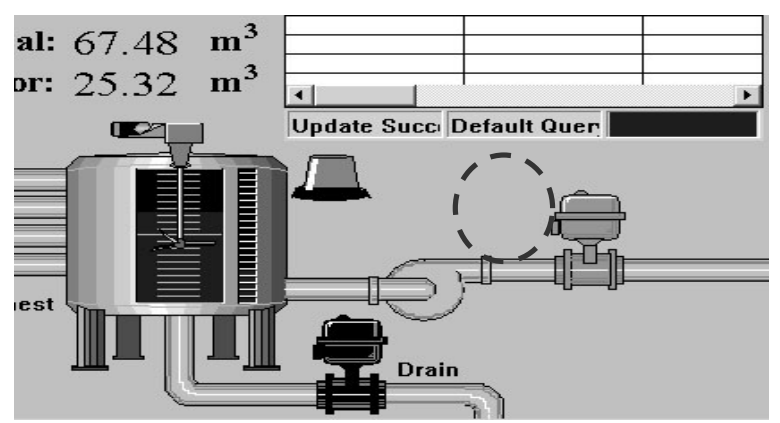

Gambar 17. End of process

Tabel 12 menunjukkan tabel hasil pencatatan database pada Microsoft Access terhadap pengujian yang dilakukan. Dari tabel di bawah dapat dperhatikan bahwa tanggal, waktu, nama resep, komposisi bahan, keterangan proses, sampai nama operator telah berhasil disimpan dengan baik setiap 5 detik.

\section{KESIMPULAN}

\section{Kesimpulan}

Dari semua proses yang dilakukan, mulai dari perencanaan, pembuatan alat, sampai dengan pengujian alat/sistem, dapat diambil beberapa kesimpulan sebagai berikut:

a. Simulator Mixing plant untuk pembuatan kertas di mana terdapat 4 buah tank bahan (NBKP, LBKP, Wet Brokes, dan Dry Brokes) dan sebuah mixing chest dapat dikontrol dari sebuah komputer dengan program SCADA dengan baik (tingkat keberhasilan $100 \%$ ). 
b. Recipe Manager digunakan untuk membuat perbandingan volume bahan (NBKP, LBKP, Wet Brokes, dan Dry Brokes) yang akan dicampur ke dalam Mixing Chest.

c. SQL Access Manager digunakan untuk mengkoneksikan dan memutuskan koneksi dengan database, membuat tabel baru dengan parameterparameter yang telah ditentukan terlebih dahulu, mencatat data yang ada pada plant sesuai dengan parameter-parameter yang telah ditentukan, serta mengakses data yang ada pada database tersebut.

Adapun pengembangan yang dapat dilakukan ialah dengan membuat SCADA software sendiri (menggunakan bahasa pemrogaman umum seperti Visual Basic ataupun Delphi) dengan kemampuan dan fitur yang sama dengan yang telah dibuat oleh Wonderware InTouch ini. Sehingga harganya lebih murah dan dapat dipakai oleh industri kecil dan menengah.

\section{DAFTAR PUSTAKA}

[1] Buku Panduan Training. Mojokerto: PT. Pabrik Kertas Tjiwi Kimia TBK
[2] C200H-AD002 Analog Input Unit Operation Manual. OMRON, 1993.

[3] C200H-AD002/DA002 Analog I/O Units Operation Guide. OMRON, 1995.

[4] C200HX/C200HG/C200HE Programmable Controllers Operation Manual. OMRON, 1996.

[5] P\&I Diagram Line 4 Stock Approach PM-12. Mojokerto: PT. Pabrik Kertas Tjiwi Kimia TBK

[6] Sutanto, William. Sistem Automasi Pada Roll Handling System PM 11 Control Area 014 di PT. Pabrik Kertas Tjiwi Kimia, TBK, Laporan Kerja Praktek Elektris Jurusan Teknik Elektro. Surabaya: Universitas Kristen Petra, 2005.

[7] Wonderware $^{\circledR}$ FactorySuite $^{\mathrm{TM}}$ InTouch $^{\circledR}$ User's $^{\text {' }}$ Guide. Invensys Systems Inc, pdf File. 2004.

[8] Wonderware FactorySuite $^{\mathrm{TM}}$ InTouch $^{\circledR}$ Reference Guide. Invensys Systems Inc, pdf File. 2002.

[9] Wonderware ${ }^{\circledR}$ FactorySuite $^{\mathrm{TM}}$ Recipe Manager User's Guide. Invensys Systems Inc, pdf File. 2002.

[10] Wonderware ${ }^{\circledR} \quad$ FactorySuite $^{\mathrm{TM}}$ SQL Access Manager User's Guide. Invensys Systems Inc, pdf File. 2002. 